Research Paper

\title{
A New Isolation Method of Human Lacrimal Canaliculus Epithelial Stem Cells by Maintaining Close Association with Their Niche Cells
}

\author{
Weikun $\mathrm{Hu}^{1}$, Yuan Zhang ${ }^{2}$, Sean Tighe ${ }^{2}$, Ying-Tieng Zhu² and Gui-Gang $\mathrm{Li}^{1}{ }^{1}$ \\ 1. Department of Ophthalmology, Tongii Hospital, Tongji Medical College, Huazhong University of Science and Technology, Wuhan, PRC. 430030 \\ 2. Tissue Tech, Inc., Ocular Surface Center, and Ocular Surface Research \& Education Foundation, Miami, FL, USA. 33173 \\ $\square$ Corresponding author: Guigang LI, M.D and Ph.D. Department of Ophthalmology, Tongji Hospital, Tongji Medical College, Huazhong University of Science \\ and Technology, 1095 Jiefang Road, Wuhan, Hubei 430030, People's Republic of China. Telephone: 86-13986046874; Fax: 86-2783663688; E-mail: guigli@163.com \\ (C) Ivyspring International Publisher. This is an open access article distributed under the terms of the Creative Commons Attribution (CC BY-NC) license \\ (https://creativecommons.org/licenses/by-nc/4.0/). See http://ivyspring.com/terms for full terms and conditions.
}

Received: 2018.06.06; Accepted: 2018.06.30; Published: 2018.07.30

\begin{abstract}
Purpose: To investigate whether lacrimal canaliculus epithelial stem cells (LCESC) could be isolated and expanded in vitro.

Methods: The lacrimal canaliculus epithelium of 6 patients with limbal stem cell deficiency (LSCD) caused by alkali burn or Stevens Johnson Syndrome were examined by lacrimal endoscope. Cadaveric eyelids were fixed and prepared for cross section and stained with $\mathrm{HE}$ and antibodies against PCK, Vim, p63a, SCF and c-Kit. Canaliculus tissue was separated under an operating microscope using a lacrimal probe as an indicator and digested with collagenase $A$. The clusters of epithelial cells with closely associated stroma were further digested with Trypsin/EDTA to obtain single cells for culture on Matrigel-coated plastic plates in MESCM media. The expression of SCF, c-Kit and p63a was determined by immunostaining. The colony-forming efficiency on 3T3 feeder layers was also measured by calculating the percentage of the clone number divided by the total number cells seeded.

Results: The epithelial layers of five out of six inferior lacrimal canaliculi and all the six superior lacrimal canaliculi were visually normal in appearance. Five to fifteen layers of the epithelium in the human lacrimal canaliculi were present with a small, tightly compacted basal layer of cells expressing PCK, p63a, SCF and c-Kit. LCESC were isolated by collagenase A and obtained clonal growth in MESCM. The colony-forming efficiency of LCESC holoclones on a 3 T3 feeder layer was $3.2 \%$, compared to $1.9 \%$ for those of limbal stem cells (LSC).

Conclusions: Herein, we first report that LCESCs can be isolated and have stem cell characteristics, similar to those of LSCs. Such a discovery raises a promising substrate resource of stem cells for LSC reconstruction in LSCD patients.
\end{abstract}

Key words: Lacrimal Canaliculus, Epithelium, Stem Cells, Niche, SCF, c-Kit and p63a

\section{Introduction}

The cornea is a transparent tissue that covers the front of the eye. The main functions of the cornea are transmitting and focusing light to enable visual perception. The cornea is composed of five layers: a non-keratinized squamous epithelium on the outer surface, a collagenous and avascular stroma, and a monolayer endothelium on the inner surface separated by a membrane, anteriorly by Bowman's layer and posteriorly by Descemet's membrane $[1,2]$.
The corneal epithelium has the important role to act as a barrier to protect the cornea and prevent infection. Every 3 to 10 days, corneal epithelium can regenerate once completely $[3,4]$, and this requires constant renewal of epithelial cells.

Epithelial stem cells are the most reliable source of adult epithelial cells due to their self-renewal ability. Interestingly, such ability is regulated in a specialized in vivo microenvironment, termed "niche" 
[5-8]. Corneal epithelial stem cells reside in the basal portion of a special structure termed the "limbal palisades of Vogt," located in the junction between the cornea and the conjunctiva [9-11]. Due to their unlimited self-renewal capacity, limbal epithelial stem cells play an important role in corneal clarity. Dysfunction of these cells and their niche has been recognized in certain ocular surface diseases manifesting as limbal stem cell deficiency (LSCD). The causative factors of LSCD include but are not limited to Stevens Johnson Syndrome, chemical and thermal burns, tumors, congenital aniridia, multiple surgeries, immunologic conditions, and various infections [10, $12,13]$. In the past decades, various methods for the reconstruction of the ocular surface have been successful in the majority of cases. For example, oral mucosa transplantation, amniotic membrane transplantation, and autograft limbal stem cell transplantation and reconstruction of the lid-ocular surface interface are used for treatment of LSCD. However, not all patients are suitable for the procedure. The main issue is the availability of donor tissue due to the shortage of donor tissues with a stem cell resource during the LSCD occurrence [14-16].

The human lacrimal drainage system is a canal-like structure consisting of an upper and lower punctum situated at the medial end of both sets of eyelids. Both puncta connect to a vertical canaliculus before turning medially and eventually joining with each other to form a common canaliculus. This part goes into lacrimal sac and then the nasolacrimal duct $[17,18]$. According to our clinical observation, most patients with LSCD have normal canaliculus epithelium. However, whether this epithelium can be a source of stem cells (SC) is unclear, and if so, how to isolate such lacrimal canaliculus epithelial stem cells (LCESC) is unknown. Herein, we demonstrate that digestion with collagenase can effectively isolate LCESCs together with their closely associated niche cells. Such isolated stem cells retain their progenitor status since the isolated cells express stem cell markers such as p63a, SCF and c-Kit. In addition, the cells form colonies when cultured with 3T3 feeder layers in vitro. These SCs may represent a new treatment option and be engineered as a surgical graft for treatment of corneal diseases such as LSCD.

\section{Materials and Methods}

\section{Lacrimal endoscope examination}

Six patients suffering from limbal stem cell deficiency (LSCD) caused by either alkali burn (4 cases) or Stevens Johnson Syndrome (2 cases) were examined by lacrimal endoscope under local infiltration anesthesia. The morphology of the epithelium was recorded and compared to that of normal people.

\section{Cell Isolation and Culture}

Canaliculus tissue was separated carefully under the operating microscope with microsurgery scissors and using a lacrimal probe as an indicator. After digestion with collagenase $\mathrm{A}$ at $37^{\circ} \mathrm{C}$ for 20 hours, the clusters of the epithelial cells and immediatecontacted mesenchymal cells were further digested with trypsin/EDTA (T/E) at $37^{\circ} \mathrm{C}$ for 15 minutes to obtain single cells. The cells were expanded in MESCM [19].

Human LSC were isolated and cultured as previously described $[19,20]$. Corneoscleral rims from 18 to 60 years old donors were obtained from The Red Cross Eye Bank of Wuhan City (Whuan, China) and managed in accordance with the declaration of Helsinki. The limbal explants were digested with collagenase $\mathrm{A}$ at $37^{\circ} \mathrm{C}$ for $18 \mathrm{~h}$ to generate clusters containing the entire limbal epithelial sheet with subjacent stromal cells. The clusters were further digested with $0.25 \%$ trypsin and $1 \mathrm{mM}$ EDTA (T/E) at $37{ }^{\circ} \mathrm{C}$ for $15 \mathrm{~min}$ to yield single cells before being seeded at a density of $1 \times 10^{4}$ per $\mathrm{cm}^{2}$ in 6-well plates coated with Matrigel in MESCM containing LIF and bFGF. Upon $80-90 \%$ confluence, the cells were serially passaged at the density of $5 \times 10^{3}$ per $\mathrm{cm}^{2}$.

\section{Colony Forming Assay}

The epithelial progenitor status of the sphere growth from LCESC and LSC was determined and compared by colony assay on 3T3 feeder layers in supplemental hormonal epithelial medium (SHEM), which is made of an equal volume of DMEM and F12 supplemented with $5 \%$ fetal bovine serum, $0.5 \%$ dimethyl sulfoxide, $2 \mathrm{ng} / \mathrm{ml} \mathrm{hEGF}, 5 \mathrm{pg} / \mathrm{ml}$ insulin, 5 $\mathrm{pg} / \mathrm{ml}$ transferrin, $5 \mathrm{ng} / \mathrm{ml}$ selenium, $0.5 \mathrm{pg} / \mathrm{ml}$ hydrocortisone, $1 \mathrm{nM}$ cholera toxin, $50 \mathrm{pg} / \mathrm{ml}$ gentamicin, and $1.25 \mathrm{pg} / \mathrm{ml}$ amphotericin $\mathrm{B}$. The feeder layer was prepared by treating $80 \%$ subconfluent $3 \mathrm{~T} 3$ fibroblasts with $4 \mathrm{pg} / \mathrm{ml}$ mitomycin $\mathrm{C}$ at $37^{\circ} \mathrm{C}$ for $2 \mathrm{~h}$ in DMEM containing $10 \%$ newborn calf serum, and then by seeding single growth-arrested 3T3 fibroblasts at a density of $2 \times 10^{4} / \mathrm{cm}^{2}$. A total of 500 single cells from 10-day cultured cells were seeded per well of a 6-well-plate in SHEM. After 9 days, epithelial clones were revealed by fixing in paraformaldehyde and staining with rhodamine B. The colony-forming efficiency (CFE) was measured by calculating the percentage of the clone number divided by the total number cells seeded. The clone morphology was subdivided into holoclone, meroclone, and paraclone based on the criteria for skin keratinocytes [21]. 


\section{HE Staining}

Eyelid tissue from two donors (32 and 58 years old) were obtained from the Red Cross Eye Bank of Wuhan City (Whuan, China) and managed in accordance with the declaration of Helsinki. Donated after death, eyelid tissue was fixed with $4 \%$ formaldehyde for 48 hours, embedded in paraffin, and prepared for 6 micrometers cross section. Hematoxylin-eosin staining was performed for selection of the preserved canaliculus tissue. The prepared tissue slides was staining with hematoxylin, rinsed in tap water, de-stained with alcohol, rinsed with tap water again and dehydrated with ethanol before microscopic evaluation.

\section{Immunostaining}

The slides from tissue cross-section were permeabilized with $0.2 \%$ Triton X-100 in PBS for 15 min, and blocked with 2\% BSA in PBS for $1 \mathrm{~h}$ before being incubated with primary antibodies (SCF, c-Kit, p63a, PCK and Vim, 1:50 dilution) overnight at $4{ }^{\circ} \mathrm{C}$. After washing with PBS, the slides were incubated with corresponding secondary antibodies for $1 \mathrm{~h}$ using appropriate isotype-matched non-specific IgG antibodies as controls. The nucleus was counterstained with Hoechst 33342 before being analyzed with a Zeiss LSM 700 confocal microscope (LSM700, Carl Zeiss. Thornhood, NY).

For immunostaining of cultured cells, single cells were prepared for cytospin using Cytofuge ${ }^{\circledR}$ at 1,000 rpm for 8 min (StatSpin, Inc., Norwood, MA), fixed with $4 \%$ formaldehyde for $15 \mathrm{~min}$, permeabilized with $0.2 \%$ Triton X-100 in PBS for $15 \mathrm{~min}$, and blocked with $2 \%$ BSA in PBS for $1 \mathrm{~h}$ before being incubated with the primary antibodies overnight at $4{ }^{\circ} \mathrm{C}$. After washing with PBS, cytospin preparations were incubated with corresponding secondary antibodies for $1 \mathrm{~h}$ using appropriate isotype-matched non-specific IgG antibodies as controls. The nucleus was counterstained with Hoechst 33342 before being analyzed with a Zeiss LSM 700 confocal microscope (LSM700, Carl Zeiss. Thornhood, NY).

\section{Statistical Analysis}

All summary data were reported as means \pm SD, calculated for each group and compared using ANOVA and the Student's paired t-test by Microsoft Excel (Microsoft, Redmont, WA). Test results were reported as two-tailed $p$ values, where $p<0.05$ was considered statistically significant.

\section{Results}

\section{LSCD patients have normal epithelial layers in the lacrimal canaliculus}

The lacrimal drainage system is composed of the lacrimal puncta, superior and inferior canaliculi, common canaliculus, lacrimal sac, and nasolacrimal duct [17]. Lacrimal endoscope is a convenient method to exam the lacrimal system. With this approach, it is possible to visualize the lacrimal canaliculus and other lacrimal part clearly. In addition, some ophthalmologists could do simple surgeries with it, for example, removing fibrous obstructions along the lacrimal canaliculus or nasolacrimal duct [22]. In our study, we performed lacrimal endoscopy examination on six patients with LSCD (four cases caused by alkali burn and the other two by Stevens Johnson Syndrome, Fig. 1). Clinical observation showed that alkali burn leads to corneal opacity, epithelial defects, and neovascularization of the cornea [23-25]. SJS involved ocular surfaces were also very similar [26].

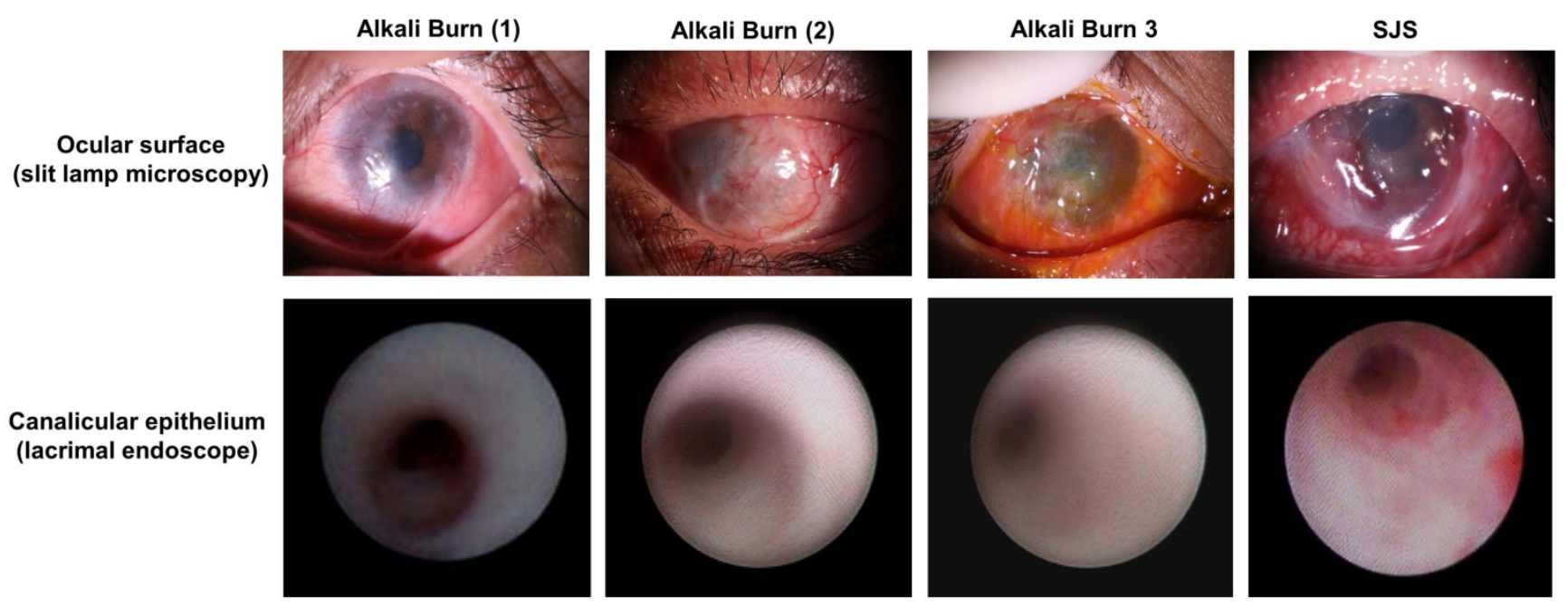

Fig. 1. LSCD patients have normal lacrimal canaliculus epithelium. Four LSCD patients were examined under slit lamp microscopy, photos show that both alkali burn (the left 3 columns) and SJS patients (the right 1 column) could have normal lacrimal canaliculus epithelium (the bottom row). Such normal lacrimal canaliculus epithelium could serve as the stem cell resource for ocular surface reconstruction. 
We found that lacrimal punctal occlusion occurred in one patient's superior lacrimal canaliculus and two patients' inferior lacrimal canaliculi. However, all the lacrimal canaliculi except one with a scar were visually normal. The canaliculus epithelial layers were smooth and healthy under lacrimal endoscope, and were not different from normal people (Fig. 1).

\section{Lacrimal canaliculus has multi epithelial layers expressing stem cell markers}

The lacrimal punctum and the vertical canaliculus are connected and encircled by dense, fibrous tissue [27-29] which is part of the tarsal plate [29]. In our study, we removed the lacrimal puncta and extra tarsal plate, thereby only retaining the canaliculus epithelium and the closely associated stroma. HE staining showed that lacrimal canaliculus is lined with stratified squamous epithelium without keratinization and mucin-production (Fig. 2A). In addition, we noted that the cells in the basal layer were small and with high nuclear cytoplasm ratio, suggesting that the cells are young. To confirm the results of the HE staining, we then performed double immunostaining on human lacrimal canaliculus sections. As expected, the expression of pan-cytokeratin (PCK) was found in the full-thickness of stratified epithelium, whereas the expression of vimentin (Vim) (Fig. 2B), which is a mesenchymal cell marker [20], was found adjacent to the basal epithelial cells. Double immunostaining also showed that c-Kit, a haematopoietic stem cell marker [30], was positive in Vim- epithelial cells (Fig. 2B), while stem cell factor (SCF) was positive in basal layer epithelial and stromal cells (Fig. 2B). The epithelial progenitor marker p63a [31] was also present in the basal layer of
PCK+ epithelial cells (Fig. 2B). Interestingly, lacrimal canaliculus epithelial stem cells lie deep in the epithelium (Fig. 2B).

\section{LCESC express stem cell markers in vitro}

Lacrimal canaliculus was separated from the eyelid using a lacrimal probe and a punctum dilator as an indicator. Subsequently, collagenase digestion yielded compacted cell aggregates, termed "clusters". These clusters could be transferred easily to tubes or other dishes with a pipette. After T/E treatment, we noted that single cells from the lacrimal canaliculus mostly adhered on Matrigel-coated plastic dishes on day 1 in MESCM (Fig. 3). The cells continued to expand, some of which formed clones during their growth with the support of closely associated niche cells, resembling a report that limbal epithelial stem cells and their niche might form clones during their growth [20]. On Day 10, the holoclones on Matrigel were composed of small, round, tightly packed with epithelial cells and surrounded by spindle-shape stromal cells. To confirm the stemness of these cells, we prepared a cytospin of single cells obtained by a brief treatment with T/E. Double immunostaining further indicated that c-Kit was found positive in both PCK+ epithelial cells and PCK- stromal cells, while SCF was found in PCK- stromal cells (Fig. 3). The stem cell marker p63a was found in most of PCK+ epithelial cells (Fig. 3). Collectively, these data suggest that collagenase isolated lacrimal canaliculus ESC could express putative SC markers.

\section{Maintenance of lacrimal canaliculus progenitor status in MESCM}

The above data prompted us to examine whether lacrimal canaliculus cells cultured in MESCM could
A
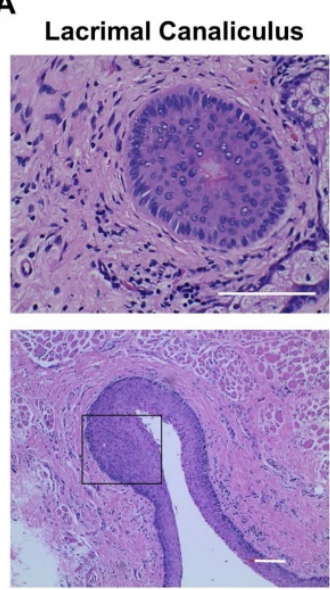

Magnified Area
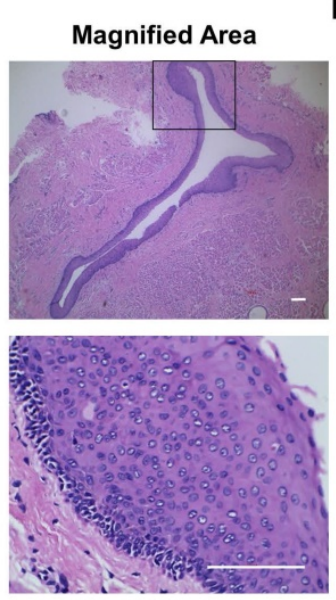

Magnified Area
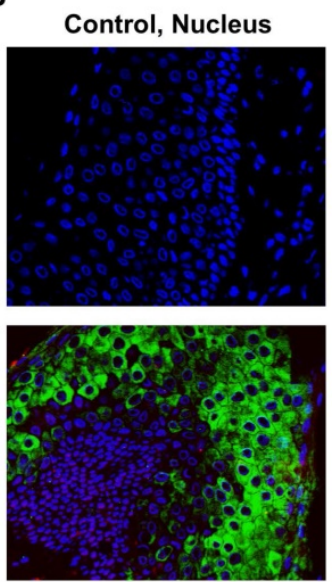

$\operatorname{PCK}(\mathrm{G}) / \mathrm{p} 63 \alpha(\mathrm{R})$
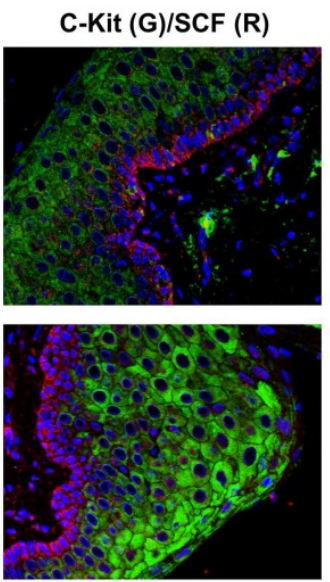

PCK (G)/SCF (R)
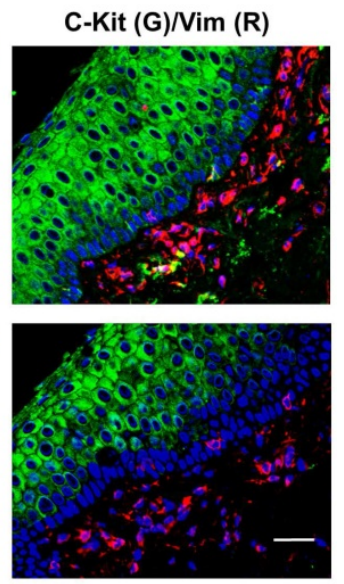

PCK (G)/Vim (R)

Fig. 2. More than 10 layers of epithelial cells in lacrimal canaliculus under HE staining (A) express stem cell markers (B). Lacrimal canaliculus under HE staining shows that the epithelial layer of lacrimal canaliculus consists of more than ten layers of epithelial cells, square in surface, small and cube in the base. More than twenty layers are at the thickest area. Bar=200 $\mu \mathrm{m}$. IF suggests that lacrimal canaliculus epithelium, especially the small and compacted epithelium, expresses stem cell markers such as p63a, SCF, c-Kit. Bar=100 $\mu \mathrm{m}$. 

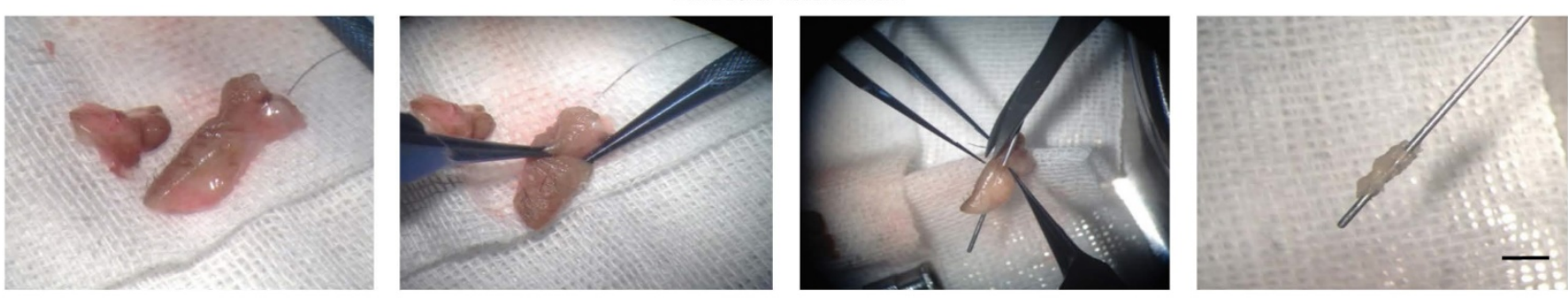

\section{LCESC Expansion}

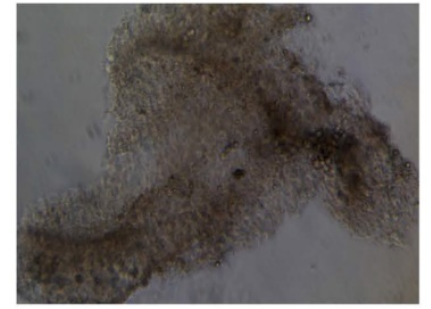

Collagenase Isolation

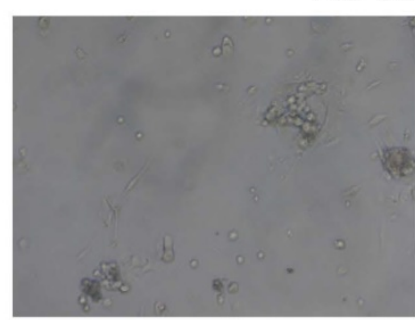

Culture, Day 1

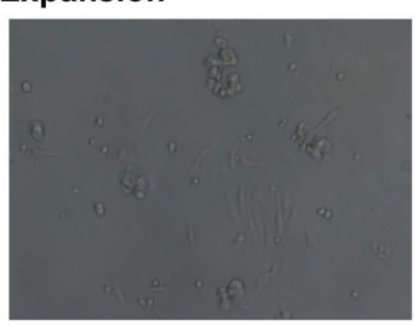

Culture, Day 2

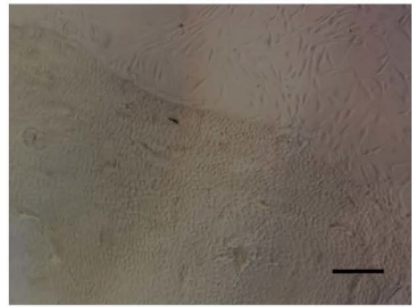

Culture, Day 14
Culture, Day 14

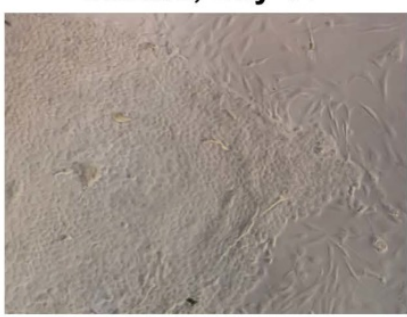

Phase

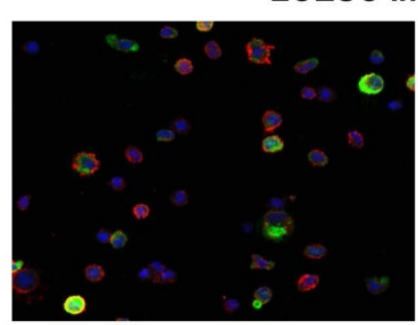

PCK (G)/c-Kit (R)
LCESC Immunostaining

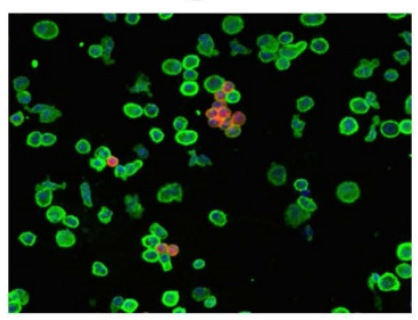

PCK (G)/SCF (R)

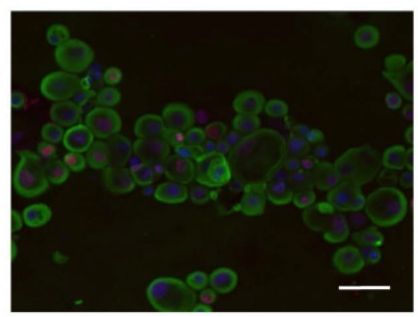

$\operatorname{PCK}(G) / p 63 \alpha(R)$

Fig. 3. Isolated LCESC by collagenase forms aggregates and clonal growth, expresses SCF, c-Kit and p63a in vitro. LCESC can be isolated by collagenase, forming aggregates and some expanding as clonal growth, expressing stem cell markers p63a, SCF, c-Kit. Bar=100 $\mu \mathrm{m}$.

maintain progenitor status. To do so, we compared clonal growth between LCESC and limbal epithelial stem cells (LSC) by seeding the density of 500 single cells per six-well plastic plate on mitomycin $C$ treated 3T3 fibroblast feeder layers in SHEM. According to the criteria reported by Barrandon [32], clones could be classified into three types by size, the smoothness of the border, and the cell size in the center of the clone, that is, holoclones, paraclones and meroclones. Among the clones, holoclones are the reliable indicator of young and likely stem cells. Rhodamine B staining performed on day 9 showed that there was no significant difference in total epithelial clones generated between LCESC and LSC (Fig. 4). However, LCESC yielded significant more holoclones and less paraclones (Fig. 4, 3.22\% $\pm 0.37 \%$ and $1.3 \% \pm 0.32 \%, n$ $=5)$ than LSC $(1.9 \% \pm 0.36 \%$ and $1.8 \% \pm 0.14 \%$, respectively, $\mathrm{p}<0.001$ and $\mathrm{p}<0.05)$, and no significant difference between them in meroclones (Fig. $4,1.5 \% \pm 0.32 \%$ and $1.9 \% \pm 0.14 \%, n=5$ ). Collectively, these data suggest that maintenance of lacrimal canaliculus progenitor status in MESCM can be performed and generates more holoclones than

\section{that of LSC.}

\section{Discussion}

Limbal stem cell deficiency (LSCD) occurs as a result of damage or disease to the limbal stem cells, which affects the corneal wound healing and surface integrity [33, 34]. LSCD can arise from diseases such as Stevens Johnson Syndrome and through injuries such as alkali burn. Characteristics of LSCD include corneal epithelial defects, neovascularization, ingrowth of the conjunctival epithelium, and chronic inflammation [23-25].These events eventually lead to visual loss [12, 35, 36]. Traditionally, treatment of LSCD patients is limbal tissue transplantation, which is obtained from a fellow healthy eye or a donor eye [37]. Recently, scientists have reported patients with ocular surface diseases can be treated by tissue-engineered epithelium [38, 39]. For example, cultivated autologous conjunctival epithelium was used for treatment of LSCD and reconstruction of corneal surface. Stem cell treatment has many advantages, such as high safety, low risk of infection and rejection, and no need for long-term immunosuppression $[38,40]$. Therefore, treatment of 


\section{Clonal Growth, LCESC and LESC on 3T3 Feeder Layer}

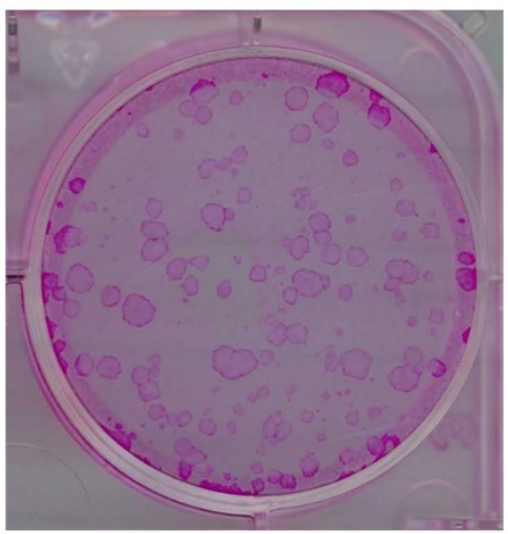

LCESC

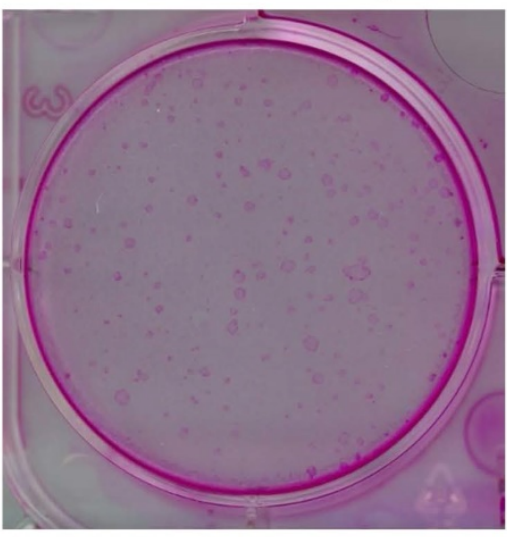

LESC

Clonal Formation Efficiency (CFE)

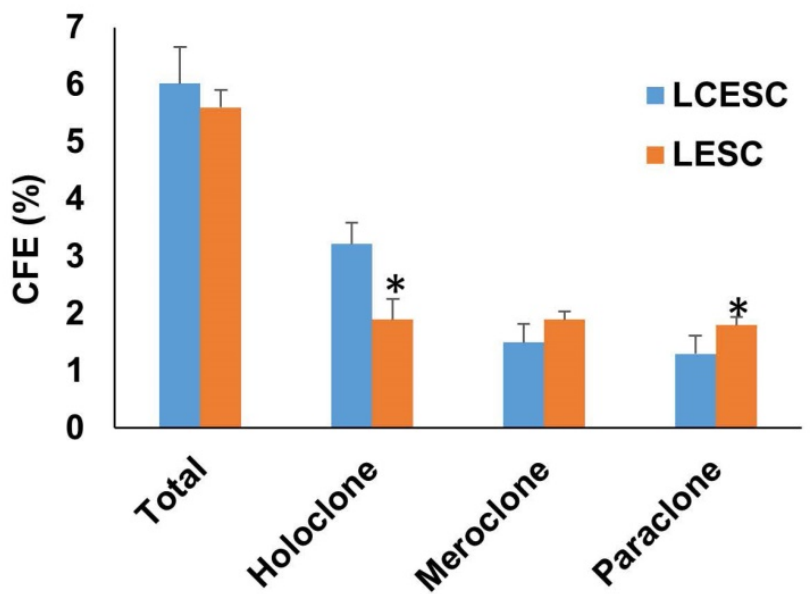

Fig. 4. Clone formation efficiency of the PO LCESC on $3 T 3$ feeder layer is better than that of LSC. The total CFE is approximately 6.0 percent including 3.2 percent holoclone, 1.5 percent macorclone and 1.3 percent paraclone in LCESC, compared to 5.6 percent including 1.9 percent holoclone, 1.9 percent macorclone and 1.3 percent paraclone in LESC. The holoclone percentage from PO LCESC is significantly higher than that of the $\mathrm{PO}$ limbal epithelial stem cells isolated by collagenase. $(\mathrm{P}<0.05)$.

LSCD patients with stem cells obtained from themselves or donors is a promising method. However, donor tissue shortage is a worldwide problem and patients with LSCD are usually complicated with severe damages on the fellow eye. This forces us to search for other alternatives. One such alternative can be found within the human lacrimal drainage system, consisting of lacrimal puncta, lacrimal canaliculi, common canaliculus, lacrimal sac, and nasolacrimal duct, which plays an important role in draining extra tear fluid into the inferior meatus of the nose $[17,41]$. Our data in this study showed that most of the lacrimal canaliculi had normal epithelial layers (Fig. 1), suggesting that the normal epithelial layers may be a stem cell source for the treatment of LSCD.

The vertical canaliculi are encircled by dense, fibrous tissue [27-29], which is considered part of the tarsal plate [29]. In our study, HE staining on canaliculus epithelium and the closely associated stroma showed that stratified squamous epithelium is small with high nuclear cytoplasm ratio cells in the basal layer (Fig. 2A), indicating that stem cells may lie deep in the epithelium. Previously, several studies have revealed that the epithelial progenitor marker p63a is a transcription factor heralding the onset of stratified epithelial morphogenesis [42, 43], and its isoform $\Delta \mathrm{Np} 63 \mathrm{a}$, is a putative marker for human limbal stem cells [44, 45]. Double immunostaining showed that p63a was in the basal layer of PCK+ epithelial cells (Fig. 2B), suggesting that LCESC exist in the basal layer. Double immunostaining also showed that c-Kit was positive in Vim- epithelial cells, while stem cell factor (SCF) was positive in basal layer epithelial and stromal cells (Fig. 2B), suggesting that the epithelial cells express the epithelial progenitor marker c-Kit while the stromal cells express the epithelial progenitor marker SCF. C-Kit, also known as CD117, is a hematopoietic stem cell marker [30] that has been found in a wide range of cells and tissues including mast cells [46, 47], melanocytes [48], vascular endothelial cells [49], interstitial cells of Cajal [50], testis [47] and of course, bone marrow [51]. c-Kit ligand SCF is widely expressed in the body by endothelial cells, fibroblasts and stromal cells [52]. The binding of SCF to c-Kit plays an important role in migration, proliferation and survival in multiple cell types [53, 54]. We suggest that such mechanistic action may be also present in human lacrimal canaliculus. Furthermore, the aforementioned tissue digested with collagenase might yield single cells with $\mathrm{T} / \mathrm{E}$ treatment. Interestingly, after 10 days of culture, the cells could form clones during their growth (Fig. 3 and 4), and the percentage of holoclones on 3T3 feeder layer were significantly higher than that of LSCs (Fig. 4), suggesting that stem cells do exist in human lacrimal canaliculus. This report resembles what has been reported previously in limbal epithelial stem cells and their niche [20]. The data of most significant is that more LCESC holoclones and less paraclones were achieved compared to LSC. This is supports our conclusion, that human lacrimal canaliculus epithelial stem cells could maintain their progenitor status by maintaining 
close association with their niche cells. To our knowledge, this is the first report that the stem cells exist in human lacrimal canaliculus, which are likely better than limbal epithelial stem cells.

Previously, several methods have been reported for engineering a surgical graft in the treatment of limbal stem cell deficiency [55-57]. In contrast to the methods that using limbal stem cells [58-60], our current study suggests we may use lacrimal canaliculus epithelial stem cells as a potential resource. Further improvement for better ex vivo expansion is needed for eventual discovery of alternative treatment methods for limbal stem cell deficiency.

\section{Acknowledgements}

Supported by the National Natural Science Foundation of China, Grant No. 81200661; 81470606 and 81570819. Hubei Province Health and Family Planning Scientific Research Project, Grant No. WJ2017M073.

\section{Competing Interests}

The authors have declared that no competing interest exists.

\section{References}

1. Nakatsu MN, Ding Z, Ng MY, Truong TT, Yu F, Deng SX. Wnt/beta-catenin signaling regulates proliferation of human cornea epithelial stem/progenitor cells. Investigative ophthalmology \& visual science. 2011; 52: 4734-41.

2. Davis J, Duncan MK, Robison WG, Jr., Piatigorsky J. Requirement for Pax6 in corneal morphogenesis: a role in adhesion. Journal of cell science. 2003; 116: $2157-67$.

3. Hanna C, Bicknell DS, O'Brien JE. Cell turnover in the adult human eye. Archives of ophthalmology. 1961; 65: 695-8.

4. Hanna C, O'Brien JE. Cell production and migration in the epithelial layer of the cornea. Archives of ophthalmology. 1960; 64: 536-9.

5. Spradling A, Drummond-Barbosa D, Kai T. Stem cells find their niche. Nature. 2001; 414: 98-104.

6. Fuchs E, Tumbar T, Guasch G. Socializing with the neighbors: stem cells and their niche. Cell. 2004; 116: 769-78.

7. Tumbar T, Guasch G, Greco V, Blanpain C, Lowry WE, Rendl M, et al. Defining the epithelial stem cell niche in skin. Science. 2004; 303: 359-63.

8. Xie T, Li L. Stem cells and their niche: an inseparable relationship. Development. 2007; 134: 2001-6.

9. Schermer A, Galvin S, Sun TT. Differentiation-related expression of a major $64 \mathrm{~K}$ corneal keratin in vivo and in culture suggests limbal location of corneal epithelial stem cells. The Journal of cell biology. 1986; 103: 49-62

10. Lavker RM, Tseng SC, Sun TT. Corneal epithelial stem cells at the limbus: looking at some old problems from a new angle. Experimental eye research. 2004; 78: 433-46.

11. Ahmad S, Figueiredo F, Lako M. Corneal epithelial stem cells: characterization, culture and transplantation. Regenerative medicine. 2006; 1: 29-44

12. Puangsricharern V, Tseng SC. Cytologic evidence of corneal diseases with limbal stem cell deficiency. Ophthalmology. 1995; 102: 1476-85.

13. Tseng SC, Chen SY, Shen YC, Chen WL, Hu FR. Critical appraisal of ex vivo expansion of human limbal epithelial stem cells. Current molecular medicine. 2010; 10: 841-50

14. Kafle PA, Singh SK, Sarkar I, Surin L. Amniotic membrane transplantation with and without limbal stem cell transplantation in chemical eye injury. Nepalese journal of ophthalmology : a biannual peer-reviewed academic journal of the Nepal Ophthalmic Society : NEPJOPH. 2015; 7: 52-5.

15. Dobrowolski D, Orzechowska-Wylegala B, Wowra B, Wroblewska-Czajka E, Grolik M, Szczubialka K, et al. Cultivated Oral Mucosa Epithelium in Ocular Surface Reconstruction in Aniridia Patients. BioMed research international. 2015; 2015: 281870.

16. Dogru $M$, Tsubota $K$. Current concepts in ocular surface reconstruction. Seminars in ophthalmology. 2005; 20: 75-93.
17. Dantas RR. Lacrimal drainage system obstruction. Seminars in ophthalmology. 2010; 25: 98-103.

18. Wawrzynski JR, Smith J, Sharma A, Saleh GM. Optical coherence tomography imaging of the proximal lacrimal system. Orbit. 2014; 33: 428-32.

19. Li GG, Zhu YT, Xie HT, Chen SY, Tseng SC. Mesenchymal stem cells derived from human limbal niche cells. Investigative ophthalmology \& visual science. 2012; 53: 5686-97.

20. Chen SY, Hayashida Y, Chen MY, Xie HT, Tseng SC. A new isolation method of human limbal progenitor cells by maintaining close association with their niche cells. Tissue engineering Part C, Methods. 2011; 17: 537-48.

21. Xie HT, Chen SY, Li GG, Tseng SC. Limbal epithelial stem/progenitor cells attract stromal niche cells by SDF-1/CXCR4 signaling to prevent differentiation. Stem cells. 2011; 29: 1874-85.

22. Haefliger IO, Piffaretti JM. Lacrimal drainage system endoscopic examination and surgery through the lacrimal punctum. Klinische Monatsblatter fur Augenheilkunde. 2001; 218: 384-7.

23. Rezaei Kanavi M, Tabeie F, Sahebjam F, Poursani N, Jahanbakhsh N, Paymanpour $\mathrm{P}$, et al. Short-term effects of extremely low-frequency pulsed electromagnetic field and pulsed low-level laser therapy on rabbit model of corneal alkali burn. Experimental eye research. 2016; 145: 216-23.

24. Ma Y, Xu Y, Xiao Z, Yang W, Zhang C, Song E, et al. Reconstruction of chemically burned rat corneal surface by bone marrow-derived human mesenchymal stem cells. Stem cells. 2006; 24: 315-21.

25. Reinshagen $\mathrm{H}$, Auw-Haedrich $\mathrm{C}$, Sorg RV, Boehringer D, Eberwein $\mathrm{P}$, Schwartzkopff J, et al. Corneal surface reconstruction using adult mesenchymal stem cells in experimental limbal stem cell deficiency in rabbits. Acta ophthalmologica. 2011; 89: 741-8

26. Chang YS, Huang FC, Tseng SH, Hsu CK, Ho CL, Sheu HM. Erythema multiforme, Stevens-Johnson syndrome, and toxic epidermal necrolysis: acute ocular manifestations, causes, and management. Cornea. 2007; 26: 123-9.

27. Murube J, Murube E. Treatment of dry eye by blocking the lacrimal canaliculi. Survey of ophthalmology. 1996; 40: 463-80.

28. Yokoi N, Nishii M, Komuro A, Kinoshita S. [New surgical methods for punctal occlusion of severe tear-deficient dry eye and its outcome]. Nippon Ganka Gakkai zasshi. 2004; 108: 560-5.

29. Takahashi Y, Kakizaki H, Nakano T, Asamoto K, Ichinose A, Iwaki M. Anatomy of the vertical lacrimal canaliculus and lacrimal punctum: a macroscopic study. Ophthalmic plastic and reconstructive surgery. 2011; 27: 384-6.

30. Li J, Quirt J, Do HQ, Lyte K, Fellows F, Goodyer CG, et al. Expression of c-Kit receptor tyrosine kinase and effect on beta-cell development in the human fetal pancreas. American journal of physiology Endocrinology and metabolism. 2007; 293: E475-83.

31. Pellegrini G, Dellambra E, Golisano O, Martinelli E, Fantozzi I, Bondanza S, et al. p63 identifies keratinocyte stem cells. Proceedings of the National Academy of Sciences of the United States of America. 2001; 98: 3156-61.

32. Barrandon $\mathrm{Y}$, Green $\mathrm{H}$. Three clonal types of keratinocyte with different capacities for multiplication. Proceedings of the National Academy of Sciences of the United States of America. 1987; 84: 2302-6.

33. Dua HS, Joseph A, Shanmuganathan VA, Jones RE. Stem cell differentiation and the effects of deficiency. Eye. 2003; 17: 877-85.

34. Chen JJ, Tseng SC. Abnormal corneal epithelial wound healing in partial-thickness removal of limbal epithelium. Investigative ophthalmology \& visual science. 1991; 32: 2219-33.

35. Kenyon KR, Tseng SC. Limbal autograft transplantation for ocular surface disorders. Ophthalmology. 1989; 96: 709-22; discussion 22-3.

36. Holland EJ, Schwartz GS. The evolution of epithelial transplantation for severe ocular surface disease and a proposed classification system. Cornea. 1996; 15: 549-56.

37. Ramaesh K, Dhillon B. Ex vivo expansion of corneal limbal epithelial/stem cells for corneal surface reconstruction. European journal of ophthalmology. 2003; 13: 515-24.

38. Ang LP, Tanioka H, Kawasaki S, Ang LP, Yamasaki K, Do TP, et al. Cultivated human conjunctival epithelial transplantation for total limbal stem cell deficiency. Investigative ophthalmology \& visual science. 2010; 51: 758-64.

39. Ricardo JR, Cristovam PC, Filho PA, Farias CC, de Araujo AL, Loureiro RR, et al. Transplantation of conjunctival epithelial cells cultivated ex vivo in patients with total limbal stem cell deficiency. Cornea. 2013; 32: 221-8.

40. Tanioka H, Kawasaki S, Yamasaki K, Ang LP, Koizumi N, Nakamura T, et al. Establishment of a cultivated human conjunctival epithelium as an alternative tissue source for autologous corneal epithelial transplantation. Investigative ophthalmology \& visual science. 2006; 47: 3820-7.

41. Xie C, Li XY, Cui HG. Potential candidate cells for constructing tissue-engineered lacrimal duct epithelium: a histological and cytological study in rabbits. Journal of Zhejiang University Science B. 2015; 16: 904-13.

42. Koster MI, Kim S, Mills AA, DeMayo FJ, Roop DR, p63 is the molecular switch for initiation of an epithelial stratification program. Genes \& development. 2004; 18: 126-31.

43. Senoo M, Pinto F, Crum CP, McKeon F, p63 Is essential for the proliferative potential of stem cells in stratified epithelia. Cell. 2007; 129: 523-36.

44. Di Iorio E, Barbaro V, Ruzza A, Ponzin D, Pellegrini G, De Luca M. Isoforms of DeltaNp63 and the migration of ocular limbal cells in human corneal regeneration. Proceedings of the National Academy of Sciences of the United States of America. 2005; 102: 9523-8. 
45. Barbaro V, Testa A, Di Iorio E, Mavilio F, Pellegrini G, De Luca M. C/EBPdelta regulates cell cycle and self-renewal of human limbal stem cells. The Journal of cell biology. 2007; 177: 1037-49.

46. Mayrhofer G, Gadd SJ, Spargo LD, Ashman LK. Specificity of a mouse monoclonal antibody raised against acute myeloid leukaemia cells for mast cells in human mucosal and connective tissues. Immunology and cell biology. 1987; 65 ( Pt 3): 241-50.

47. Majumder S, Brown K, Qiu FH, Besmer P. c-kit protein, a transmembrane kinase: identification in tissues and characterization. Molecular and cellular biology. 1988; 8: 4896-903.

48. Nocka K, Majumder S, Chabot B, Ray P, Cervone M, Bernstein A, et al Expression of c-kit gene products in known cellular targets of $\mathrm{W}$ mutations in normal and $\mathrm{W}$ mutant mice--evidence for an impaired c-kit kinase in mutant mice. Genes \& development. 1989; 3: 816-26.

49. Broudy VC, Kovach NL, Bennett LG, Lin N, Jacobsen FW, Kidd PG. Human umbilical vein endothelial cells display high-affinity c-kit receptors and produce a soluble form of the c-kit receptor. Blood. 1994; 83: 2145-52.

50. Torihashi S, Ward SM, Nishikawa S, Nishi K, Kobayashi S, Sanders KM. c-kit-dependent development of interstitial cells and electrical activity in the murine gastrointestinal tract. Cell and tissue research. 1995; 280: 97-111.

51. Wang C, Curtis JE, Geissler EN, McCulloch EA, Minden MD. The expression of the proto-oncogene C-kit in the blast cells of acute myeloblastic leukemia. Leukemia. 1989; 3: 699-702.

52. Heinrich MC, Dooley DC, Freed AC, Band L, Hoatlin ME, Keeble WW, et al. Constitutive expression of steel factor gene by human stromal cells. Blood. 1993; 82: 771-83.

53. Okumura N, Tsuji K, Ebihara Y, Tanaka I, Sawai N, Koike K, et al. Chemotactic and chemokinetic activities of stem cell factor on murine hematopoietic progenitor cells. Blood. 1996; 87: 4100-8.

54. Lammie A, Drobnjak M, Gerald W, Saad A, Cote R, Cordon-Cardo C. Expression of c-kit and kit ligand proteins in normal human tissues. The journal of histochemistry and cytochemistry : official journal of the Histochemistry Society. 1994; 42: 1417-25.

55. Pellegrini G, Traverso CE, Franzi AT, Zingirian M, Cancedda R, De Luca M. Long-term restoration of damaged corneal surfaces with autologous cultivated corneal epithelium. Lancet. 1997; 349: 990-3.

56. Schwab IR, Reyes M, Isseroff RR. Successful transplantation of bioengineered tissue replacements in patients with ocular surface disease. Cornea. 2000; 19: 421-6.

57. Shimazaki J, Aiba M, Goto E, Kato N, Shimmura S, Tsubota K. Transplantation of human limbal epithelium cultivated on amniotic membrane for the treatment of severe ocular surface disorders. Ophthalmology. 2002; 109: 1285-90.

58. Tsai RJ, Li LM, Chen JK. Reconstruction of damaged corneas by transplantation of autologous limbal epithelial cells. The New England journal of medicine. 2000; 343: 86-93.

59. Sangwan VS, Vemuganti GK, Iftekhar G, Bansal AK, Rao GN. Use of autologous cultured limbal and conjunctival epithelium in a patient with severe bilateral ocular surface disease induced by acid injury: a case report of unique application. Cornea. 2003; 22: 478-81.

60. Nakamura T, Inatomi T, Sotozono C, Ang LP, Koizumi N, Yokoi N, et al. Transplantation of autologous serum-derived cultivated corneal epithelial equivalents for the treatment of severe ocular surface disease. Ophthalmology. 2006; 113: 1765-72 